\title{
Mobile Learning in University Contexts Based on the Unified Theory of Acceptance and Use of Technology (UTAUT)
}

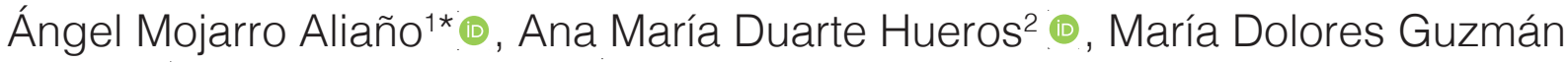 \\ Franco $^{3}$ (1) Ignacio Aguaded ${ }^{4}$ () \\ 'Departamento de Educación, Universidad de Huelva, Spain \{angel.mojarro@alu.uhu.es\} \\ 2Dirección Enseñanza Virtual, Universidad de Huelva, Spain \{duarte@uhu.es\} \\ 32Departamento de Educación, Universidad de Huelva, Spain\{maria.guzman@dedu.uhu.es\} \\ ${ }^{4}$ Departamento de Educación, Universidad de Huelva, Spain \{aguaded@uhu.es\} \\ Received on 16 May 2018; revised on 22 May 2018; accepted on 31 May 2018; published on 15 January 2019
}

DOI: 10.7821/naer.2019.1.317

(cc) BY-NC-ND

\begin{abstract}
The aim of this study is to determine the factors that significantly influence the acceptance and intent to use smartphones and tables as resources for learning in university contexts, as well as the relationships established between them. For their analysis, we followed a contextualized model of evaluation starting with the methodological framework of the Unified Theory of Acceptance and Use of Technology (UTAUT), proposed by Venkatesh and collaborators (2003). For this, a data collection instrument was designed, validated to our context and optimized for mobile learning and the education community. A total of 370 university students participated in the study. From the statistical analysis conducted, it was shown that the instrument constructed had a notable internal consistency, showing a high validity for collecting information in relation to five of the eight factors of which it was composed, although it should be revised in relation to the other three. Also, through the data collected, a high pre-disposition was observed for the use of mobile devices for learning, with a direct effect on the constructs validated, as well as the socio-demographic variables (age, gender, degree year and field of knowledge) that could be considered moderating variables of this pre-disposition. Although these results could be put into context in future studies, it can be concluded that the instrument design can be a good indicator of the pre-disposition towards the use of mobile learning strategies.
\end{abstract}

KEYWORDS: EDUCATIONAL TECHNOLOGY, RELIABILITY, QUESTIONNAIRE, MOBILE LEARNING.

\section{INTRODUCTION}

The consumption of digital media by the youth and teens at social, personal and educational levels has become the compass of different studies and research in the last decade. International organizations such as the UN, UNESCO (2013, 2014), among others, have highlighted that the future contains a wealth of sig-

*To whom correspondence should be addressed:

Departamento de Educación - Facultad de Ciencias de la Educación Campus de El Carmen - Avda. Tres de Marzo s/n - 21007 Huelva (Spain) nificant technological changes that will be accompanied by new learning scenarios, and that the expansion of mobile technology will not be parallel to its effective and productive integration. Scientific research in this filed has lead to a revolution in the open learning of the students in the university context.

Studies such as the one by Liu, Scordino, Geurtz, Navarrete, Yujung Ko \& Lim (2014); Cabero \& Barroso (2016); Major, Hassler \& Hennessy (2017), among others, have evidenced the interest in the use of the mobile devices in teaching contexts, their contributions and the repercussions on the student's learning results. Other works have described the appearance of addictive behaviors due to their excessive use in the teaching and personal domains (Castellana et al., 2007; Cuesta \& Gaspar, 2013; Rodríguez-Gómez et al., 2018), or the consequences of the use of mobile phones by the citizens, and the need to offer user guidelines and norms and to opt for a model of mediation for the use of mobile communication (Park \& Karan, 2014).

Another research line that has been growing is related to the use of the mobile phone with the results achieved in learning (Crompton, Burke, \& Gregory, 2017), contributing to and enriching the construction of knowledge by the students (Daher, 2010) and increasing their motivation and commitment as well (Dündar \& Akçayir, 2014; Long, Liang, \& Yu, 2013; Miller \& Cuevas, 2017; Tay, 2016).

The mobile learning strategies arose as a consequence of transferring their use to the classrooms as an additional learning tool, promoting ubiquitous learning, able to be conducted at any time and place. The educational strategies mediated by mobile devices are the subjects that guide this research, through which the factors that directly influence the intent to use of these technologies of the sample studied will be identified.

Through the analysis of the literature on the state of the art, the benefits of these mobile learning strategies have been empirically confirmed (Contreras, Herrera, \& Ramírez, 2009). Now, according to the systematic literature review conducted on educational research linked to mobile learning, the number of studies on mobile learning is still located at an early stage of development; as shown by the systematic study conducted on the time interval from 2002 to the present. 


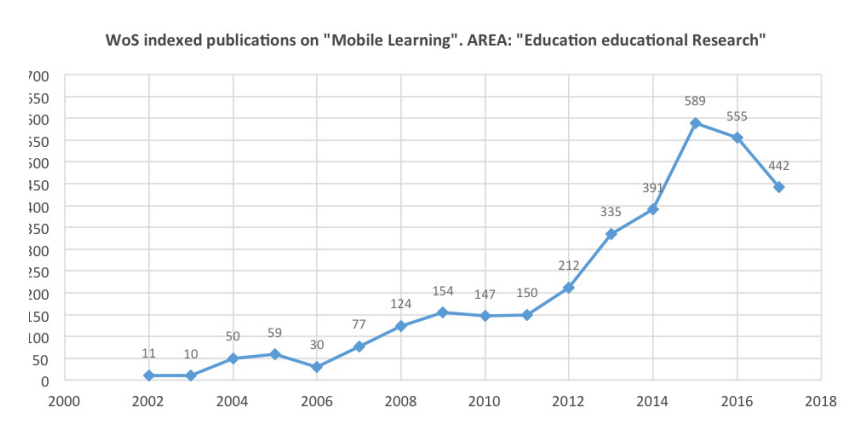

Figure 1. Publications indexed in WoS about "mobile learning", area: "Education Educational Research"

This data makes it evident that the evolution and interest by academia started in the year 2007, as related to the mobile learning strategies in Higher Education. Nevertheless, in the year 2010, a more pronounced increase was observed, sharply increasing in the years 2015 and 2016, with 589 and 555 indexed studies, respectively. Of the 3336 total references, only 19 were linked to technology acceptance models.

As for the use and integrations of mobile devices in the educational context, Peters (2007) and Wagner (2015) opted for the ones that developed and promoted learning, emphasizing among their potential, the possibility of learning at any time and place, the efficient access to information, the improvement of the teaching interaction in an asynchronous and synchronous manner, the flexibility to personalize learning according to the student's rhythm and style, the motivation it provides to the students, the improvement in communication between the students and the educational institutions and the development of collaborative learning (Gutiérrez-Porlán \& al., 2018), among other advantages.

As related to the ability to learn through mobile devices, authors such as Corbell \& Valdés-Corbell (2007), Kolb (2008) and Ramos-Soler et al. (2018) have proposed the possibilities of correct use of the smartphone to favor significant learning, linked to social reality, enriching the educational experiences through multimedia resources, facilitating communication and educational and social collaboration, motivating the students towards learning, or favoring the creation of new content by the students and teachers.

In summary, the most relevant strength of the previous analysis is that one should not think of mobile learning as the experience of using mobile devices with traditional methodology, but instead one should opt for innovation to improve the processes of teaching and interaction (Ramirez-Montoya \& García Peñalvo, 2017).

The review, contextualization and analysis of this study is framed within the UTAUT research model, created for the understanding of the intent to use a new system of information and communication in a specific area, independently of the nature of the activity. Donaldson (2011) highlights the ideal nature of this model for understanding the behavioral intent of the use of mobile devices as a tool for learning, as well as its acceptance in the education sphere.

\section{METHODOLOGY}

The main purpose that structured this research was to inquire into the factors that affect the technological acceptance and intent to use mobile learning strategies among the university students, based on the research model of the Unified Theory of Acceptance and Use of Technology (UTAUT). Thus, the research proposes the understanding of the student's perceptions with respect to the integration of the mobile devices in the classroom, the design of a valid and reliable instrument to understand the acceptance and intent to use of these strategies, and based on the results, to contribute to the construction of a new model of technological acceptance based on the UTAUT.

It should be indicated that although the first model of the theory drafted by Venkatesh et al (2003) was used as a reference, it was necessary to perform a series of modifications and adaptations of the instrument for this study in particular, by omitting the dependent variable final use and the moderating variable experience of use, as in our context, learning through a mobile device is a process that is still in its first phase of growth and experimentation, with the learning experiences conducted being scarce. Also, it should be adapted to learning with mobile devices, so that two variables considered to be moderators of the effect of the independent variables on the dependent variable (age and gender), according to the recommendations by other authors (Wang, Wu, \& Wang, 2009), were added. Also, the integration of other data related to the socio-demographic variables (degree year and field of knowledge) were also integrated, with the aim of verifying if they also possessed the moderator character with respect to the relationships among the different factors analyzed.

Table 1. Types of variables and codes for the study

\begin{tabular}{|c|c|}
\hline Type & Variable Codes \\
\hline Moderating Variables & $\begin{array}{l}\text { Gender, Age, Degree year, Field of } \\
\text { Knowledge }\end{array}$ \\
\hline \multirow{7}{*}{ Independent Variables } & Performance Expectancy (PE) \\
\hline & Effort Expectancy (EE) \\
\hline & Social Influence (SI) \\
\hline & Voluntariness to Use (WU) \\
\hline & Facilitating Conditions (FC) \\
\hline & Self-management of Learning (SL) \\
\hline & Perceived Gratification (PG) \\
\hline Dependent Variables & Behavioral Intention (BI) \\
\hline
\end{tabular}

A graphical representation of the theoretical model expected is shown in Figure 2:

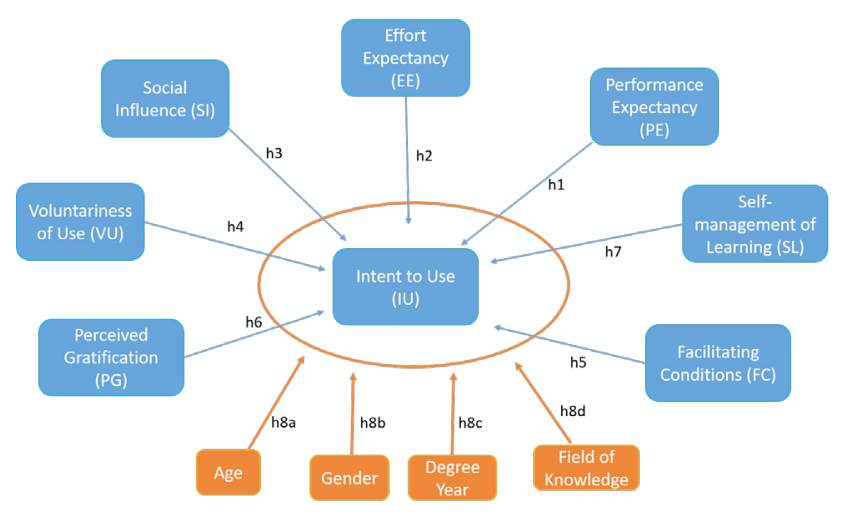

Figure 2. Theoretical UTAUT theoretical model proposed in the study

However, to reach this model, it was necessary to previously have available a model that allowed for the obtaining, in a valid and reliable manner, the data necessary to verify the accuracy of the model proposed. This previous process will be the focus of the present study. 


\subsection{Phases of the study}

The sequence of the methodology followed the structure of other research studies dedicated to the analysis of the acceptance and the use of technology (Davis, 1989; Venkatesh \& Davis, 2000; Venkatesh et al., 2003, among others). Starting with the results from the review of the state of the art of the strategies of mobile learning, from the point of view of the acceptance of technology, the theory of UTAUT was selected, as it was considered to be ideal for achieving the objectives proposed in the study. Once the variables and the dimensions of analysis to be considered were determined, a questionnaire was constructed based on the theory cited, adapting it to the use of mobile devices.

To ensure the suitability of the instrument, it was validated with the expert judgement technique. These experts were selected due to their specialization in the university sector, educational technology, communication, and research methodologies. Once the instrument was reviewed, based on the expert's suggestions, a pilot test was developed with a sample of students who had similar characteristics as the final sample. This allowed for conducting the final adjustments and verification of the level of reliability and validity, as a whole, as well as related to each of the constructs included within it.

This initial test resulted in an instrument that was optimized for its use in the final study presented here. The questionnaires were given during the months of April-June of 2015, in a self-administered manner.

Once the data were collected, in order to ensure the validity of the constructs proposed, and following the recommendations of other studies (Arteaga, Duarte, \& García, 2013; Morata et al., 2015; Zumbo, 2007), the adjusted goodness-of-fit index was once again verified, by analyzing its internal consistency from the statistical point of view. In addition, this consistency was also calculated for the items included to ensure that they measured what they should, discarding those that did not have sufficient validity, continuing with the analysis of adequacy and factorial weight of the rest in each of the constructs according to what they were considered for, through a principal component analysis. Ultimately, the instrument's degree of statistical explanation was found for the model proposed.

\subsection{Sample}

The sample of participants was composed of a total of 370 Bachelor's degree students from the University of Huelva. The sample was randomly selected, stratified as a function of age, gender, field of knowledge and degree year in which they were. The sample selection was conducted in this manner as "it is a type of sampling that is highly recommended, especially for large populations... [...] and, if the results are to be extrapolated to the entire population, they can be related to the dependent variable" (Morales Vallejo, 2012, p. 3).

\subsection{Instrument and adjustment of the model of measurement}

An ad hoc questionnaire was utilized for the development of this study. In order to ensure the validity and the reliability of the instrument, this was subjected to a double procedure of validation: a two-round expert judgement and a posterior pilot study, once it was revised and corrected according to the expert's suggestions. Its reliability and internal consistency, as tested with Cronbach's Alpha, was found to be high (0.907).

In the end, as shown in Table 3, the questionnaire was structured into 8 dimensions. The first of which was composed of items related to the moderating socio-demographic variables included in the study (gender, age, field of knowledge and degree year). The next 7 constituted a total of 28 items which used a semantic differential scale with Likert-type responses from 1 to 6 , similar to the original instrument proposed in the UTAUT, and related to the study variables assimilated to each one of the dimensions selected.

Table 3. Dimensions of the instrument and number of items included in each one of them

\begin{tabular}{lc}
\hline \multicolumn{1}{c}{ Dimensions of the questionnaire } & N. Items/ variables \\
\hline (1) Socio-demographic data & 4 \\
(2) Performance expectancy & 4 \\
(3) Effort expectancy & 4 \\
(4) Social influence & 3 \\
(5) Voluntariness of Use & 3 \\
(6) Facilitating conditions & 4 \\
(7) Self-management of learning & 4 \\
(8) Perceived gratification & 4 \\
(9) Behavioral intention & 2 \\
\hline
\end{tabular}

\section{ANALYSIS OF RESULTS}

The analysis of the results was conducted with the SPSS v21 software. The reliability and consistency of the instrument were verified, again obtaining a high Cronbach's Alpha (0.880) and the descriptive statistics figures were calculated for each of the items (mean, mode, median, standard deviation, maximums and minimums). Their validity was also measured, to be included in the measurement of each of the constructs that were proposed, and the correlations between them were also calculated, for the posterior observation of their relationships with the BI dependent variable. As the restriction criteria, those items whose exclusion could result in the increase of Cronbach's Alpha, or that had an item-total correlation lower than 0.3, were eliminated (Ajzen \& Fishbein, 1998).

Table 2. Sample characteristics (moderating variables)

\begin{tabular}{|c|c|c|c|c|c|c|c|c|c|c|c|}
\hline Gender & f & $\%$ & Age & f & $\%$ & Field & f & $\%$ & Year & f & $\%$ \\
\hline Male & 121 & $32,70 \%$ & $17-19$ & 51 & $13,80 \%$ & Arts and Humanities & 27 & $7,30 \%$ & $1 \mathrm{st}$ & 54 & $14,60 \%$ \\
\hline Female & 249 & $67,30 \%$ & $20-22$ & 196 & $53,00 \%$ & $\begin{array}{l}\text { Social and Judicial } \\
\text { Sciences }\end{array}$ & 238 & $64,30 \%$ & 2nd & 146 & $39,50 \%$ \\
\hline \multirow[t]{4}{*}{ TOTAL } & 370 & $100,00 \%$ & $23-25$ & 89 & $24,10 \%$ & Health Sciences & 20 & $5,40 \%$ & $3 \mathrm{rd}$ & 151 & $40,80 \%$ \\
\hline & & & 25 & 34 & $9,10 \%$ & $\begin{array}{l}\text { Architecture and } \\
\text { Engineering }\end{array}$ & 70 & $18,90 \%$ & 4 th & 19 & $5,10 \%$ \\
\hline & & & TOTAL & 370 & $100,00 \%$ & Sciences & 15 & $4,10 \%$ & TOTAL & 370 & $100,00 \%$ \\
\hline & & & & & & TOTAL & 370 & $100,00 \%$ & & & \\
\hline
\end{tabular}


Thus, the following items were suppressed from the analysis: PE1 (When using mobile learning strategies, I think that time will pass sooner), VU2 (My professors expect me to learn though mobile learning) and FC4 (In general, my University would support the use of mobile learning), so that a higher index of internal consistency was found (0.891) (Table 4).

Table 4. Reliability statistics (Cronbach's Alpha of the scale)

\begin{tabular}{ccc}
\hline Cronbach's Alpha & $\begin{array}{c}\text { Cronbach's Al- } \\
\text { pha based on the } \\
\text { distinct elements }\end{array}$ & N of elements \\
\hline 0,891 & 0,896 & 24 \\
\hline
\end{tabular}

Once the first step was taken, a Cronbach's Alpha was obtained for each of the sub-scales included in the instrument, which were to be used to measure the constructs related to each of the dependent and independent variables (Table 5).

As can be observed, the ones related to the variables social influence (SI), intent to use (IU) and self-management of learning (SL) did not exceed the degrees of confidence needed, but the others did have a statistically high reliability $(0.891>0.7)$.

Once the reliability of the instrument was confirmed, the inter-elements correlations analysis was performed, taking into account only the variables of the sub-scales that obtained an appropriate Alpha, in order to revise the pattern of relationships (Pearson's r); as well as to ascertain, through different statistical tests, if it was relevant to conduct a factorial analysis with the information available, through the Kaiser-Meyer-Olkin coefficient $(\mathrm{KMO}>0.6)$ and Barlett's sphericity test, which decides if the null hypothesis that the variables are inter-correlated $(\alpha=$ 0.05 ) should be accepted or not. As observed in the summary of the inter-elements correlations of the means of the sub-scales in Appendix A, there are significant correlations at 0.01 among all the items and their corresponding sub-scales. Thus, the validity of the constructs can be ensured, so that the factorial analysis will be more relevant according to the measurement of the sample's appropriateness $\mathrm{KMO}(0.851>0.06)$, and in agreement with the significance level obtained with Bartlett's sphericity test (.000), as observed in Appendix B.

Table 5. Statistics results of reliability for each sub-scale (Cronbach's Alpha)

\begin{tabular}{lccc}
\hline Sub-scale & $\begin{array}{c}\text { Cronbach's } \\
\text { Alpha }\end{array}$ & $\begin{array}{c}\text { Cronbach's Alpha } \\
\text { based on the } \\
\text { distinct elements }\end{array}$ & $\begin{array}{c}\text { N of } \\
\text { elements }\end{array}$ \\
\hline EP & 0,843 & 0,847 & 4 \\
EE & 0,833 & 0,832 & 4 \\
SI & 0,374 & 0,365 & 3 \\
WU & 0,569 & 0,572 & 2 \\
FC(1and3) & 0,775 & 0,776 & 2 \\
PE & 0,794 & 0,77 & 4 \\
$(2,3,4)+S L 3$ & & 0,524 & 3 \\
SL & 0,516 & 0,745 & 2 \\
BI & 0,745 & & \\
\hline
\end{tabular}

After the first process was finalized, the optimum number of factors or dimensions was determined, through an exploratory factorial analysis or principal components with Kaiser Varimax rotation, as this rotation is frequently used with this type of analysis, and is appropriate when the number of components is reduced. The result was the existence of four principal components that explained $72 \%$ of the total variance, as shown in Appendix C, which shows the results related to the total variance explained.

The resulting matrix of rotated components presented in Table 6 shows how the different items of each factor are grouped, from a statistical point of view.

According to these results, we can observe that the items related to the last components were maintained, as expected in the initial model of the scale (Facilitating Conditions and Behavioral

Table 6. Matrix of rotated components

\begin{tabular}{|c|c|c|c|c|}
\hline \multirow[b]{2}{*}{ Matrix of rotated components (a) } & \multicolumn{4}{|c|}{ Component } \\
\hline & 1 & 2 & 3 & 4 \\
\hline EE1- "Working through M-Learning would be a clear and comprehensible task" & 0,743 & 0,237 & 0,376 & 0,011 \\
\hline EE3- "The use of M-Learning during my learning would be easy for me" & 0,615 & 0,111 & 0,507 & $-0,01$ \\
\hline EE4- "Learning how to use M-Learning approaches in my learning would be very easy for me" & 0,757 & 0,108 & 0,412 & $-0,016$ \\
\hline PG2- "When using M-Learning, I will more easily remember the work I have to do" & 0,737 & 0,304 & $-0,015$ & 0,19 \\
\hline PE2 - "Using M-Learning strategies would allow me to complete my tasks faster" & 0,757 & 0,3 & $-0,033$ & 0,24 \\
\hline PE4- "If I used M-Learning approaches, my possibilities of obtaining better grades would increase" & 0,745 & 0,361 & $-0,058$ & 0,162 \\
\hline PG3- "Using M-Learning will make learning more enjoyable" & 0,2 & 0,773 & 0,08 & $-0,072$ \\
\hline PG4- "Using M-Learning will stimulate my curiosity" & 0,231 & 0,725 & $-0,011$ & 0,238 \\
\hline EE2- "Becoming more skillful in the use of M-Learning strategies during my learning would be very easy" & 0,241 & 0,743 & 0,321 & 0,001 \\
\hline PE1- "Using M-Learning approaches during my learning would be very useful" & 0,298 & 0,67 & 0,159 & 0,381 \\
\hline PE3- "If I used M-Learning approaches, my probabilities of obtaining better grades would increase" & 0,271 & 0,744 & 0,204 & 0,228 \\
\hline FC1 - "I have the necessary resources to teach myself through M-Learning" & $-0,001$ & 0,353 & 0,766 & 0,25 \\
\hline $\begin{array}{l}\text { FC3- "A specific group or person, technicians or advisers should be available to provide assistance with } \\
\text { problems when using M-Learning approaches" }\end{array}$ & 0,186 & 0,061 & 0,84 & 0,064 \\
\hline BI2- "I intend to use M-Learning in the next few months" & 0,249 & 0,005 & 0,067 & 0,877 \\
\hline BI1- "I foresee myself using M-Learning in the next few months" & 0,008 & 0,307 & 0,158 & 0,8 \\
\hline
\end{tabular}

Method of extraction: Principal component analysis

Method of rotation: Kaiser Varimax normalization 
Intention). Moreover, as related to the first two, we can observe that the first one groups items focused on simplicity, clarity and performance expected by the users in relation to the use of mobile learning strategies, while the second component groups those referring to the enjoyment and usefulness the users believe these strategies could provide. In any case, it was observed that the results required new revisions in future research work in order to fine tune the items that were more correct for the constructs that could play a role in the a new model based on the UTAUT.

On the other hand, as related to the study of the direct effect of the independent variables and the moderating variables on the acceptance and intent to use of the mobile devices for learning, in accordance to the perspective of the university students, the more significant results obtained in each one of them is now described, exclusively focusing on those that are related to the variables that had a sufficient validity.

In this sense, as observed in Appendix D which shows Pearson's correlation results, all the independent variables related with the scales Performance Expectancy (PE), Effort Expectancy (EE), Facilitating Conditions (FC) and Perceived Gratification $(P G)$ had statistically significant relationships $(>0.01)$ with the dependent variable Intent to Use (IU).

As for the relationship between the moderating variables (age, gender, field of knowledge and degree year) and the rest of the variables, it can be observed in the same table, the existence of an inverse relationship between age and performance expectancy, as well as the effort expectancy and the perceived gratification variable, without finding significant differences as far as the user's opinions are concerned according to age with respect to the facilitating conditions and the intent to use.

In the case of the variable gender, the results indicated that there were no significant differences between both as related to the performance and effort expectancies, but there were differences in opinion according to gender as for the facilitating conditions, with this relationship being greater with respect to the women according to the men's opinions. Likewise, there were significant differences in relation to the intent to use that seemed greater in the case of the men.

As for the field of knowledge of the students, there were no significant differences with respect to the intent to use, but differences were found in relation to the rest of the independent variables, which re-enforces the original idea that this variable could exert not a direct influence, but a moderating one, on the independent variables and not directly on the intent to use, as it occurs with age.

Lastly, as for degree year, this did not seem to affect neither the performance expectancy nor the effort expectancy, although it did have an effect as far as the facilitating conditions and the intent to use, with an inverse relationship found with the latter, when the academic year is lower, the intent to use is greater.

\section{DISCUSSION}

According to the analysis of the data, as for the perceptions of the students on their intent to use and their acceptance of mobile devices for learning, it was observed that the performance expectancy (PE), as well as the effort expectancy (EE) had a direct and important influence on their inclination, although with specific undertones that should be taken into account, in agreement with results obtained in other research studies.

In fact, it could be said that in relation to the performance expectancy, the participants positively evaluated it due to motivational and reduction in time for performing the tasks factors rather than for the possibility of improving their scores.

As related to the effort expectancy, it was observed that it also exerted a direct influence on the intent to use. The digital environment is a natural space for the youth, they have lived with it since they were born, and the fact that it is an educational strategy or a hard to understand task, they do not attribute it to the use of mobile devices, but to other reasons such as the type of task that must be developed during the learning process. Therefore, one should consider that it is possible that in the near future the inclusion of this variable in the research model will no longer be valid. This idea coincides with the study conducted by Koszalka \& Ntloedibe-Kuswani (2010), which highlights the urgent need to explore real-world uses of the mobile devices for training and the analysis of strategies that are implemented, in order to capitalize on their potential.

As for the facilitating conditions, it was observed that the university students considered it important to know how to resolve problems and incidents that are presented to them, although what they valued more significantly was the institutional assistance and technical support.

The results obtained with respect to the variable perceived gratification and its influence on the intent to use, were similar to those obtained in previous research studies. The analysis conducted after corroborating this relationship was based on that in general terms, working in an environment with digital devices results in increased motivation, producing greater personal satisfaction. This makes it so that the process of learning becomes more fun, provoking a greater interest in the students when facing the acquisition of new knowledge. These results come close to those obtained in studies conducted by Ciampa, 2014; Dündar \& Ciampa (2014), Dündar and Akçayır (2014), Miller and Cuevas (2017), and Tay (2016).

As for the variables Social Influence (SI), Self-Efficacy (SE) and Voluntariness of Use (VU), the relevant analysis could not be conducted, due to the lack of reliability of their corresponding sub-scales, so that they could not be analyzed if we were dealing with factors that had an influence on the intent to use mobile learning by the participating subjects, or their relationships with the rest of the variables, therefore we believed that it was necessary to revise the data collection instrument and to conduct a new analysis in order to offer conclusive results.

\section{CONCLUSIONS}

Based on the results obtained, and the analysis conducted referring to the instrument designed ad hoc, it could be verified that it had a high consistency and validity for gathering information related to five of the eight constructs that composed it (performance expectancy, effort expectancy, perceived gratification, facilitating conditions and intent to use). However, it was also confirmed that the instrument should be adjusted to obtain valid and reliable information with respect to the other three constructs: social influence, self-management of learning and voluntariness of use, with the object of being able to analyze their possible influence on the intent to use mobile learning strategies.

On the other hand, based on the data collected, it can be concluded that the university students had a high pre-disposition towards the use of mobile devices for learning, with a direct relationship with the constructs that were able to be validated, as well as a clear effect over them, and on the behavioral intent, of the demographic variables analyzed. Although it is necessary to conduct a more-detailed analysis on the character of the relationship that is established between them, with the aim of estimating if we are dealing with moderating or independent variables.

Another future research line should be oriented towards the design and implementation of an invigoration and training plan for university professors on the use of digital devices, approach to good practice (García, Guerrero \& Granados, 2015), design of experienc- 
es and production of content for mobile learning environments that contributes with improvements to current training models

Lastly, as recommended future lines of work, it is considered important to add the possibility of conducting longitudinal studies. The limitations of time limited this research study to adopt a cross-sectional shape, which has contributed valuable and reliable information, but it could be conditioned to the moment in time it was conducted. For this, it would also be interesting to conduct a study with the same dimensions but extended to various points in time, so that a more faithful image of the perceptions of the subjects is obtained.

\section{FUNDING}

This work was backed by the Coordinated R\&D + innovation Project entitled "Media competencies of the citizens in emergent digital media (smartphones and tablets): innovating practices and edu-communication strategies in multiple contexts", with ID

EDU2015-64015-C3-1-R (MINECO/FEDER), financed by the European Regional Development Plan (ERDP) and the Ministry of Economy and Competitiveness of Spain.

\section{REFERENCES}

Ajzen, I., \& Fishbein M. (1998). Understanding attitudes and predicting social behavior. New Jersey: Prentice-Hall.

Arteaga, R., Duarte, A., \& García, M. (2013). E-learning and the University of Huelva: a study of WebCT and the technological acceptance model. Campus-Wide Information Systems, 30(2), 135-160. doi:10.1108/10650741311306318

Bartlett, M. S. (1950). Tests of significance in factor analysis. British Journal of Statistical Psychology, 3(2), 77-85. doi:10.1111/j.2044-8317.1950.tb00285.x

Cabero, J., \& Barroso, J. M. (2013). La utilización del juicio de experto para la evaluación de TIC: el coeficiente de competencia experta. Bordón. Revista de Pedagogía, 65(2), 25-38. doi:10.13042/brp.2013.65202

Cabero, J., \& Barroso, J. (2016). The Educational Possibilities of Augmented Reality. Journal of New Approaches in Educational Research, 5(1), 44-50.

Castellana, M., Sánchez-Carbonell, X., Jordana, C. G., \& Fargues, M. B. (2007). El adolescente ante las tecnologías de la información y la comunicación: Internet, móvil y videojuegos. Papeles Del Psicólogo, 28(3), 196-204.

Ciampa, K. (2014). Learning in a mobile age: an investigation of student motivation. Journal of Computer Assisted Learning, 30, 82-96. doi:10.1111/jcal.12036

Contreras, J., Herrera, A., \& Ramírez, M. S. (2009). Elementos instruccionales para el diseño y la producción de materiales educativos móviles. Revista Apertura de Innovación Educativa, 5(11). Retrieved from https://goo.gl/KTB1Sw

Corbeil, J. R., \& Valdés-Corbell, M. E. (2007). Are you Ready for mobile learning? Educase Quarterly, 30(2), 51-58. Retrieved from https://goo.gl/jvxBnF

Crompton, H., Burke, D., \& Gregory, K. H. (2017). The use of mobile learning in PK-12 education: A systematic review. Computers \& Education, 110, 51-63. doi:10.1016/j.compedu.2017.03.013

Cuesta, U., \& Gaspar, S. (2013). Análisis motivacional del uso del Smartphone. Historia y Comunicación Social, 18, 435-447.

Daher, W. (2010). Building mathematical knowledge in an authentic mobile phone environment. Australasian Journal of Educational Technology, 26(1), 85-104. doi:10.14742/ajet.1104

Davis, F. D. (1989). Perceived usefulness, perceived ease of use, and user acceptance of information technology. MIS Quarterly, 13(3), 318-339. doi:10.2307/249008

Donaldson, R. L. (2011). Student Acceptance of Mobile Learning. Tallahassee, Florida: Florida State University. Retrieved from https://goo.gl/oyofNy

Dündar, H., \& Akçayir, M. (2014). Implementing tablet PCs in schools: Students' attitudes and opinions. Computers in Human Behavior, 32, 40-46. doi:10.1016/j. chb.2013.11.020

García, A., Guerrero, R., \& Granados, J. (2015). Buenas prácticas en los entornos virtuales de enseñanza-aprendizaje. Revista Cubana de Educación Superior, 34(3), 76-88. Retrieved from https://goo.gl/0UIfYt

Gutiérrez-Porlán, I., Román-García, M., \& Sánchez-Vera, M. (2018). Strategies for the communication and collaborative online work by university students. [Estrategias para la comunicación y el trabajo colaborativo en red de los estudiantes universitarios]. Comunicar, 54, 91-100. doi:10.3916/C54-2018-09

Kolb, D. (2008). Experiential Learning: Experience as the Source of Learning and Development. New Jersey: Prentice Hall.

Koszalka, T. A., \& Ntloedibe-Kuswani, G. S. (2010). Literature on the safe and disruptive learning potential of mobile technologies. Distance Education, 31(2), 139-157. doi: $10.1080 / 01587919.2010 .498082$
Liu, M., Scordino, R., Geurtz, R., Navarrete, C., Ko, Y., \& Lim, M. (2014). A Look at Research on Mobile Learning in K-12 Education from 2007 to the Present. Journal of Research on Technology in Education, 46(4), 325-372. doi:10.108 0/15391523.2014.925681

Long, T., Liang, W., \& Yu, S. (2013). A study of the tablet computer's application in $\mathrm{K}-12$ schools in China. International Journal of Education and Development using Information and Communication Technology, 9(3), 61-70.

Major, L., Hassler, B., \& Hennessy, S. (2017). Tablets in schools: impact, affordances and recommendations. In A. Marcus-Quinn \& T. Hourigan (Eds.), Handbook for Digital Learning in K-12 Schools (pp. 115-128). Cham: Springer.

Martín García, A., García del Dujo, A., \& Muñoz Rodríguez, J. (2014). Factores determinantes de adopción de blended learning en educación superior. Adaptación del modelo UTAUT. Educación XX1, 17(2), 217-240.

Mengual, S. (2011). La importancia percibida por el profesorado y el alumnado sobre la inclusión de la competencia digital en educación superior. Un análisis en ciencias de la actividad física y el deporte de la Universidad de Alicante (Doctoral Dissertation). Universidad de Alicante, Alicante.

Miller, H. B., \& Cuevas, J. A. (2017). Mobile Learning and its Effects on Academic Achievement and Student Motivation in Middle Grades Students. International Journal for the Scholarship of Technology Enhanced Learning, 1(2), 91-110.

Morales Vallejo, P. (2012). Tamaño necesario de la muestra: ¿Cuántos sujetos necesitamos? Estadistica aplicada, 24, 1-24. Retrieved from https://goo.gl/QPZCCj

Morata-Ramirez, M. Á., Holgado Tello, F. P., Barbero-García, M. I., \& Méndez, G. (2015). Análisis factorial confirmatorio. Recomendaciones sobre mínimos cuadrados no pondzerados en función del error Tipo I de Ji-Cuadrado y RMSEA [Confirmatory factor analysis. Recommendations for unweighted least squares method related to Chi-Square and RMSEA]. Acción Psicológica, 12, 7-90. doi:10.5944/ap.12.1.14362

Park, Ch., \& Karan, K. (2014). Unraveling the relationships between smartphone use, exposure to heterogeneity, political efficacy, and political participation: a mediation model approach. Asian Journal of Communication, 24(4), 370-389. doi:10.1080/01292986.2014.892146

Peters, K. (2007). M-learning: Positioning educators for a mobile, connected future. International Journal of Research in Open and Distance Learning, 8(2), 1-17.

Ramírez-Montoya, M. S., \& García Peñalvo, F. J. (2017). La integración efectiva del dispositivo móvil en la educación y en el aprendizaje. RIED: Revista Iberoamericana de educación a distancia, 20(2), 29-47. doi:10.5944/ ried.20.2.18884

Ramos-Soler, I., López-Sánchez, C., \& Torrecillas-Lacave, T. (2018). Online risk perception in young people and its effects on digital behaviour. [Percepción de riesgo online en jóvenes y su efecto en el comportamiento digital]. Comunicar, 56, 71-79. doi:10.3916/C56-2018-07

Rodríguez-Gómez, D., Castro, D., \& Meneses, J. (2018). Problematic uses of ICTs among young people in their personal and school life. [Usos problemáticos de las TIC entre jóvenes en su vida personal y escolar]. Comunicar, 56, 91-100. doi:10.3916/C56-2018-09

Salcines, I., González, N., \& Briones, N. (2017). Docentes universitarios: Conocimiento y uso profesional del Smartphone. Bordón. Revista de Pedagogía, 2, 37-46.

Tay, H. Y. (2016). Longitudinal study on impact of iPad use on teaching and learning. Journal Cogent Education, 3(1), 1-22. doi:10.1080/2331186X.2015.1127308

UNESCO. (2013). Directrices para las politicas de aprendizaje móvil. Retrieved from https://goo.gl/eVRgoy

UNESCO. (2014). El futuro del aprendizaje móvil. Retrieved from https://goo.gl/ $\mathrm{KpCpFQ}$

Venkatesh, V., \& Davis, F. D. (2000). A Theoretical Extension of the Technology Acceptance Model: Four Longitudinal Field Studies. Management Science, 45(2), 186-204. doi:10.1287/mnsc.46.2.186.11926

Venkatesh, V., Morris, M. G., Davis, G. B., \& Davis, F. D. (2003). User acceptance of information technology: Toward a unified view. MIS Quarterly, 27(3), 425478. doi: $10.2307 / 30036540$

Wagner, E. D. (2015). Enabling Mobile Learning. EDUCAUSE Review, 40(3), 40-53.

Wang, Y., Wu, M., \& Wang, H. (2009). Investigating the Determinants and Age and Gender Differences in the Acceptance of mobile learning. British Journal of Educational Technology, 40(5), 92-118. doi:10.1111/j.14678535.2007.00809.x

Zumbo, B. D. (2007). Validity: Foundational Issues and Statistical Methodology. En C. R. Rao \& S. Sinharay (Eds.), Handbook of Statistics, Vol. 26: Psychometrics (pp. 45-79). Amsterdam: Elsevier Science.

How to cite this article: Guzmán Franco, M. D., Duarte Hueros, A. M., Mojarro Aliaño, Á., \& Aguaded, I. (2019). Mobile Learning in University Contexts Based on the Unified Theory of Acceptance and Use of Technology (UTAUT). Journal of New Approaches in Educational Research, 8(1), 7-17. doi:10.7821/naer.2019.1.317 


\section{APPENDIX}

Appendix A. Inter-element correlations of subscale averages

\begin{tabular}{|c|c|c|c|c|c|c|}
\hline & & RE1 & RE2 & RE3 & RE4 & REsum \\
\hline \multirow{3}{*}{ PEsum } & Sig. (bilateral) & .000 & .000 & .000 & .000 & \\
\hline & $\mathrm{N}$ & 370 & 370 & 370 & 370 & 370 \\
\hline & & EE1 & EE2 & EE3 & EE4 & EEsum \\
\hline \multirow{2}{*}{ EEsum } & $\mathrm{N}$ & 370 & 370 & 370 & 370 & 370 \\
\hline & & $\mathrm{FC} 1$ & FC3 & FCsum & & \\
\hline \multirow[t]{2}{*}{ FCsum } & Pearson Correlation & $.900(* *)$ & $.908(* *)$ & 1 & & \\
\hline & Sig. (bilateral) & .000 & .000 & & & \\
\hline \multirow[t]{4}{*}{ PGsum } & Pearson Correlation & $.805(* *)$ & $.764(* *)$ & $.794(* *)$ & $.709(* *)$ & 1 \\
\hline & Sig. (bilateral) & .000 & .000 & .000 & .000 & \\
\hline & $\mathrm{N}$ & 370 & 370 & 370 & 370 & 370 \\
\hline & & BI1 & $\mathrm{BI} 2$ & BIum & & \\
\hline \multirow[t]{3}{*}{ IUsum } & Pearson Correlation & $.895(* *)$ & $.890(* *)$ & 1 & & \\
\hline & Sig. (bilateral) & .000 & .000 & & & \\
\hline & $\mathrm{N}$ & 370 & 370 & 370 & & \\
\hline
\end{tabular}

**The correlation is significant at level 0.01 (bilateral)

Appendix B. KMO and Bartlett's testInter-element correlations of subscale averages

\begin{tabular}{lll}
\hline Kaiser-Meyer-Olkin sample adequacy measurement. & \multicolumn{1}{c}{$\mathbf{8 5 1}$} \\
\hline \multirow{3}{*}{ Bartlett's test of sphericity } & Approximate Chi-Squared & 3266.831 \\
& gl & 105 \\
& Sig. & .000 \\
\hline
\end{tabular}

Appendix C. Total Variance Explained

\begin{tabular}{|c|c|c|c|c|c|c|c|c|c|}
\hline \multirow{2}{*}{ Component } & \multicolumn{3}{|c|}{ Initial Eigenvalues } & \multicolumn{3}{|c|}{$\begin{array}{l}\text { Sumas de las saturaciones al cuadra- } \\
\text { do de la extracción }\end{array}$} & \multicolumn{3}{|c|}{ Rotation Sums of Squared Loadings } \\
\hline & Total & $\begin{array}{l}\% \text { of } \mathrm{Va}- \\
\text { riance }\end{array}$ & Cumulative $\%$ & Total & $\begin{array}{l}\% \text { of Va- } \\
\text { riance }\end{array}$ & $\underset{\%}{\text { Cumulative }}$ & Total & $\begin{array}{l}\% \text { of } \mathrm{Va}- \\
\text { riance }\end{array}$ & Cumulative $\%$ \\
\hline 1 & 6.517 & 43.444 & 43.444 & 6.517 & 43.444 & 43.444 & 3.585 & 23.903 & 23.903 \\
\hline 2 & 1.623 & 10.819 & 54.263 & 1.623 & 10.819 & 54.263 & 3.294 & 21.958 & 45.861 \\
\hline 3 & 1.418 & 9.451 & 63.714 & 1,418 & 9.451 & 63.714 & 2.070 & 13.800 & 59.661 \\
\hline 4 & 1.248 & 8.317 & 72.030 & 1.248 & 8.317 & 72.030 & 1.855 & 12.369 & 72.030 \\
\hline 5 & .783 & 5.219 & 77.249 & & & & & & \\
\hline 6 & .741 & 4.937 & 82.186 & & & & & & \\
\hline 7 & .455 & 3.033 & 85.219 & & & & & & \\
\hline 8 & .421 & 2.809 & 88.028 & & & & & & \\
\hline 9 & .335 & 2.233 & 90.261 & & & & & & \\
\hline 10 & .317 & 2.116 & 92.377 & & & & & & \\
\hline 11 & .284 & 1.894 & 94.271 & & & & & & \\
\hline 12 & .267 & 1.780 & 96.051 & & & & & & \\
\hline 13 & .236 & 1.571 & 97.622 & & & & & & \\
\hline 14 & .199 & 1.325 & 98.947 & & & & & & \\
\hline 15 & .158 & 1.053 & 100.00 & & & & & & \\
\hline
\end{tabular}

Extraction Method: Principal Component Analysis. 


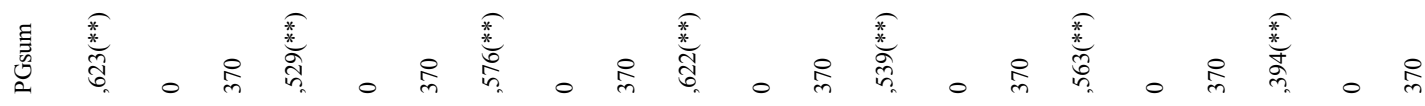

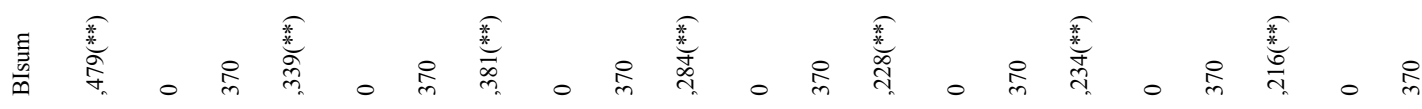

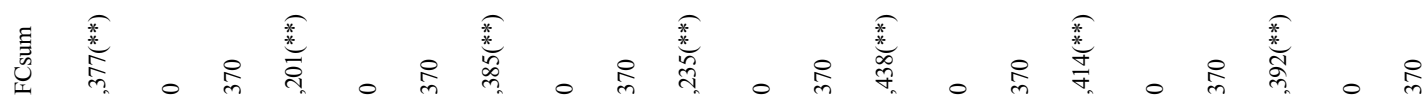

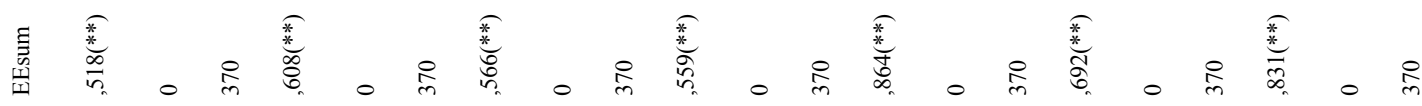

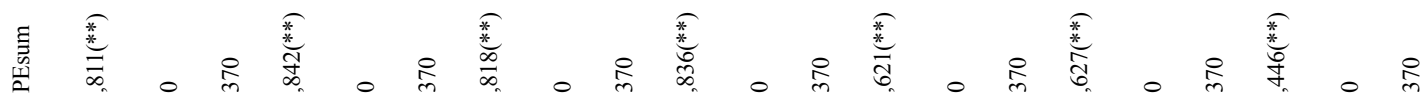

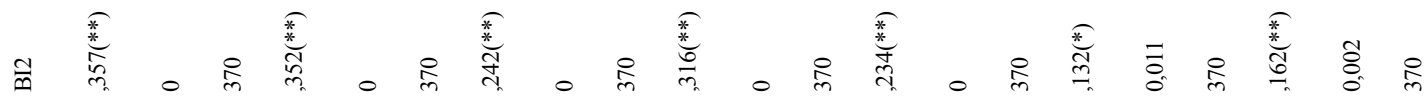

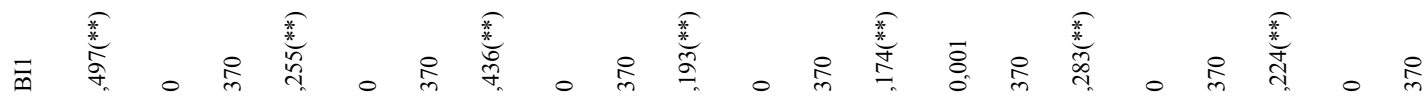

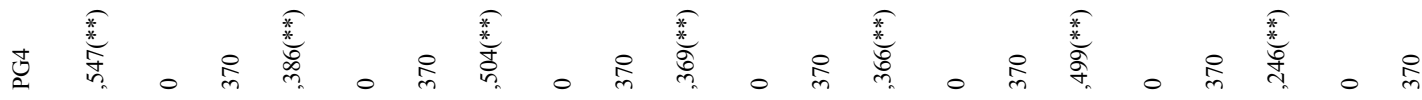

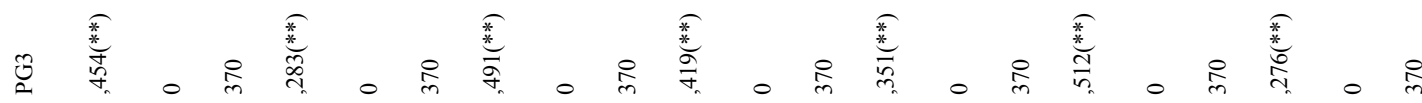

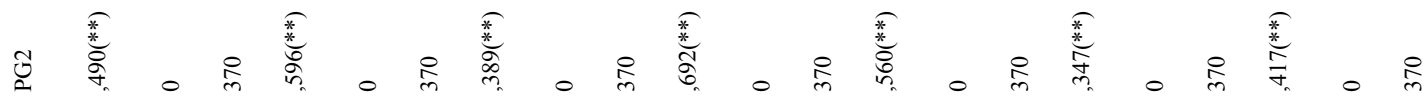

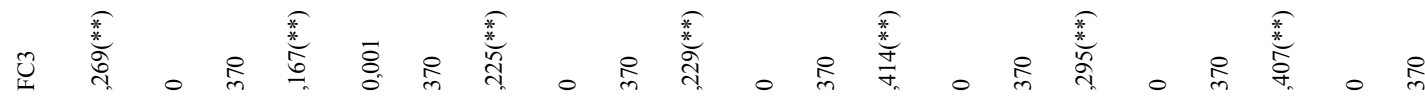

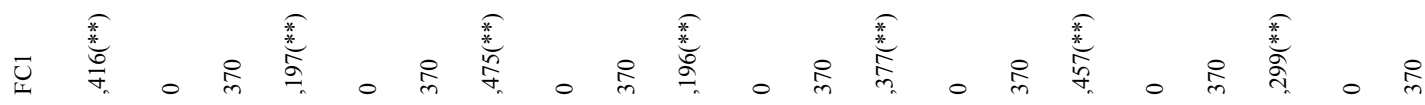

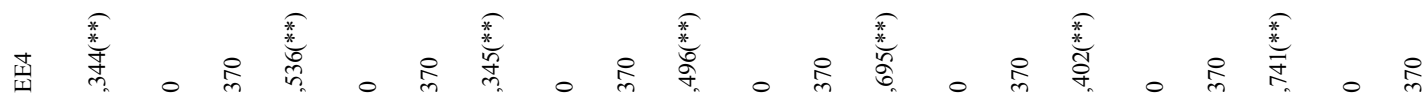

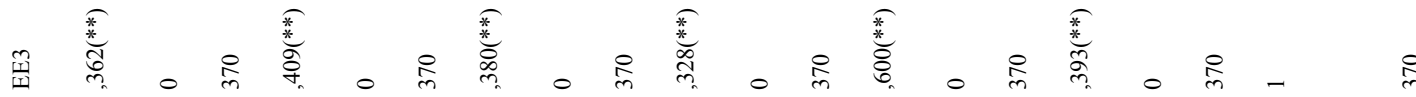

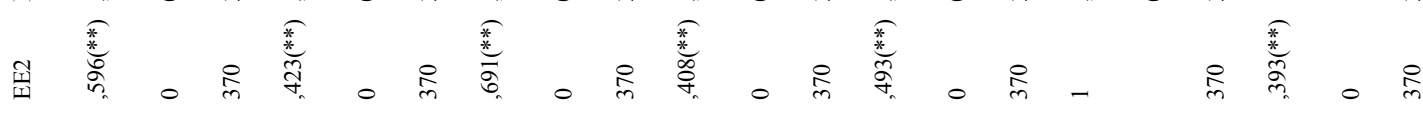

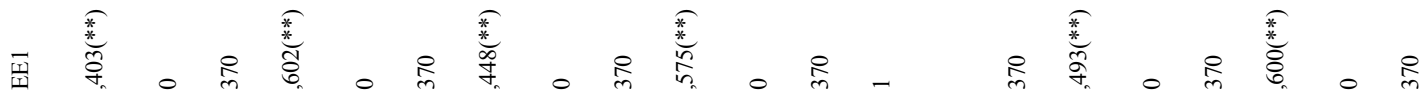

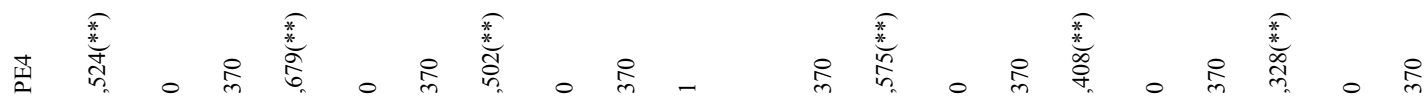

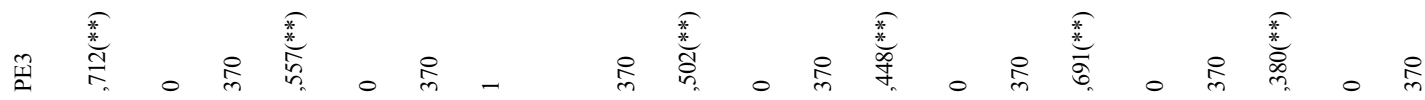

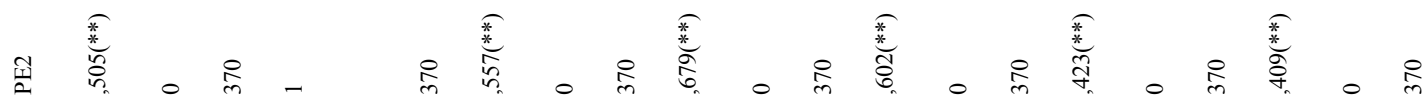

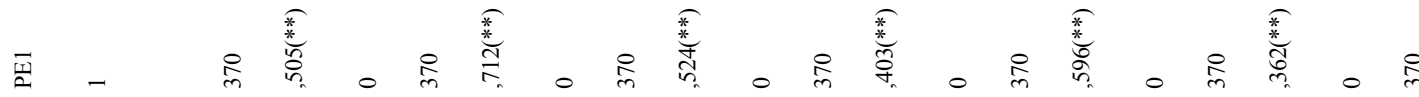

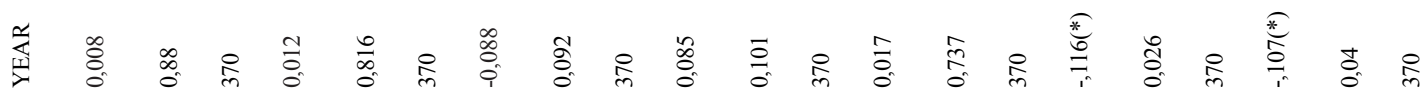

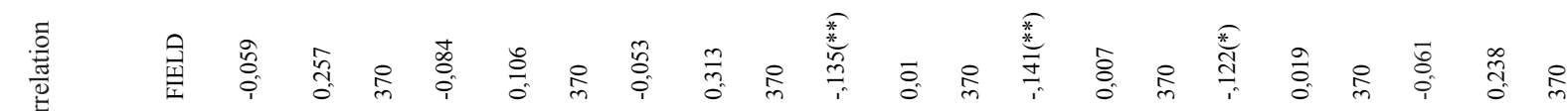

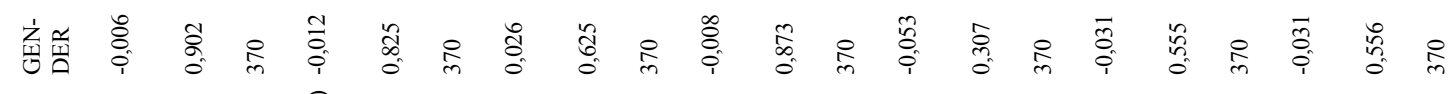

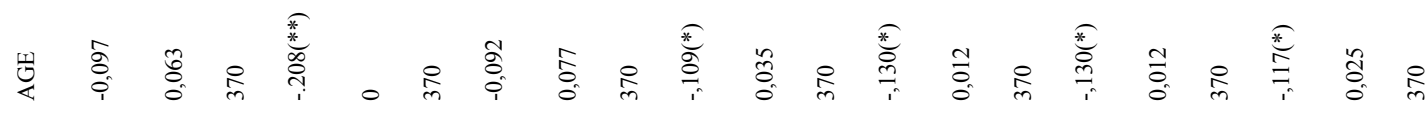

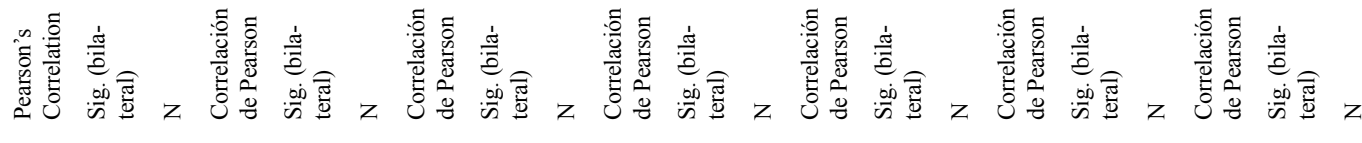
풀 풀 욜 䓍 画 


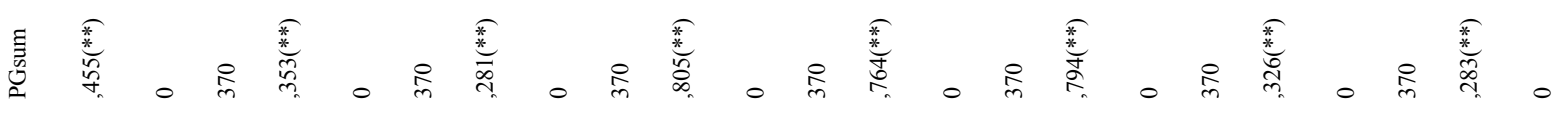

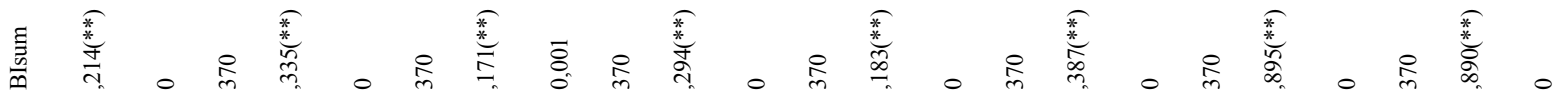
㔄悉

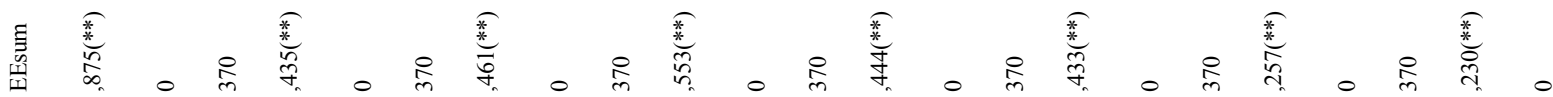

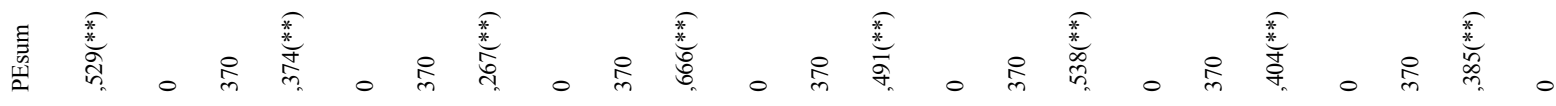

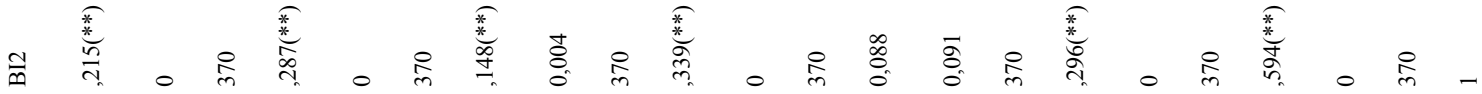

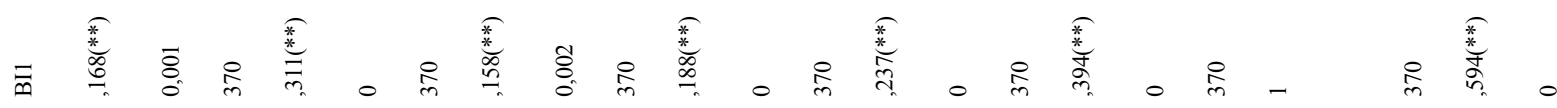

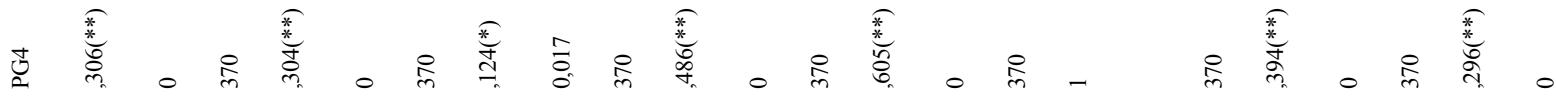
ภ

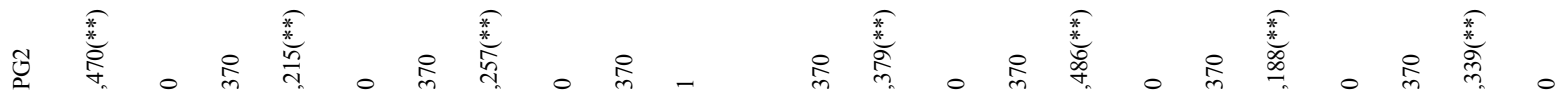

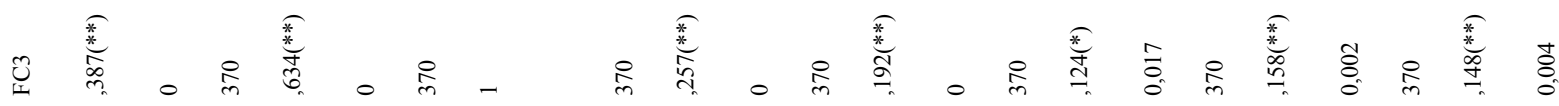

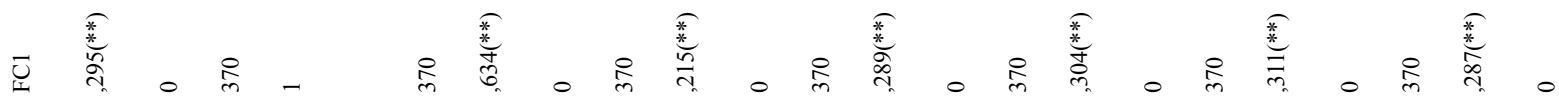

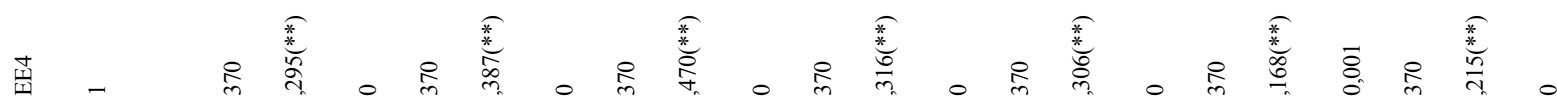

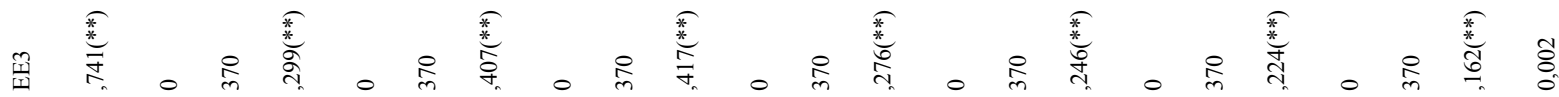

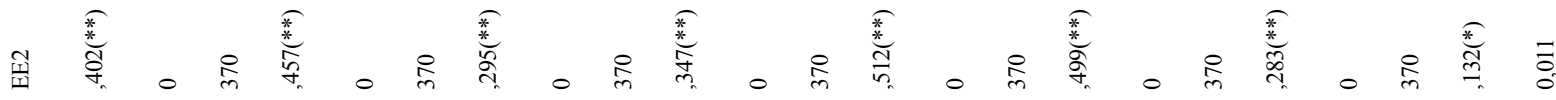

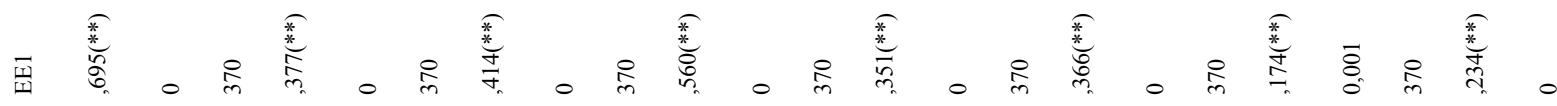

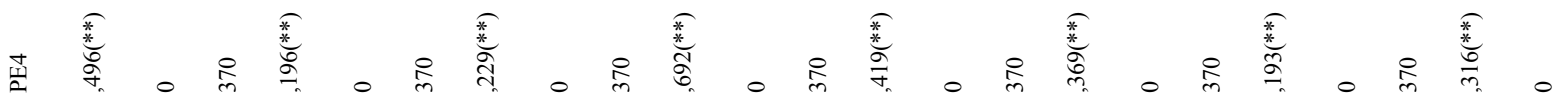

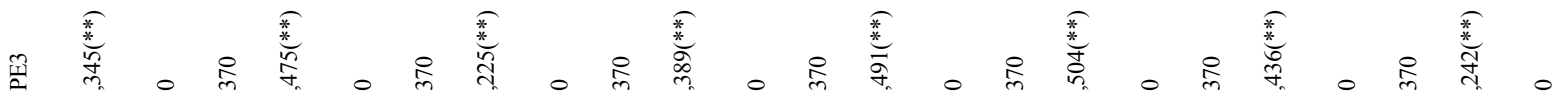

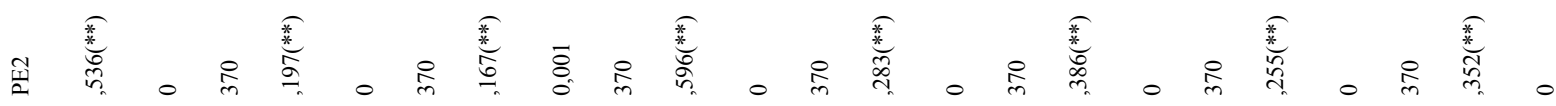

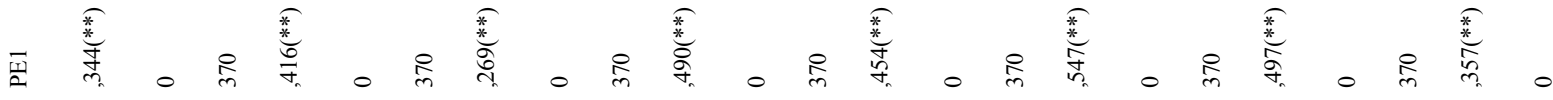

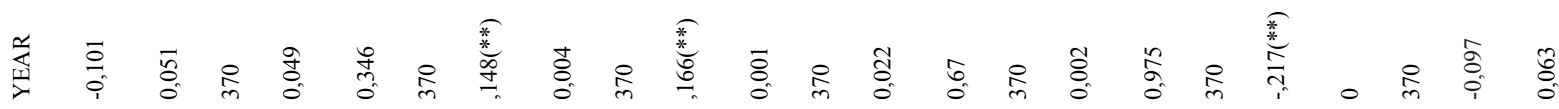

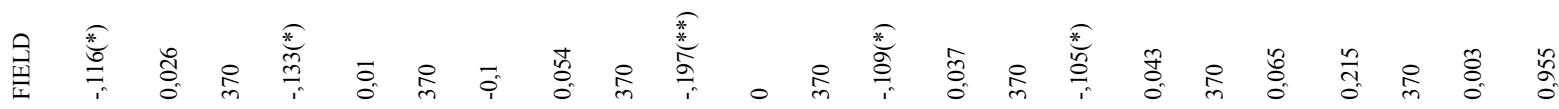

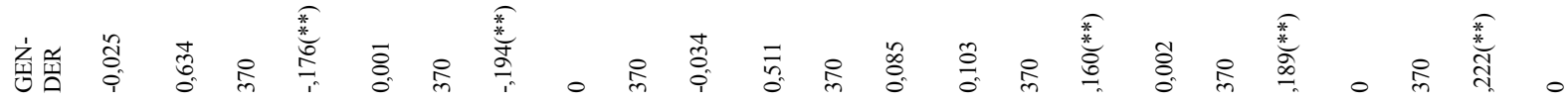

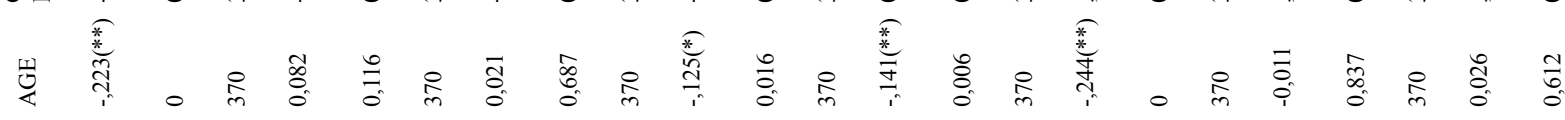

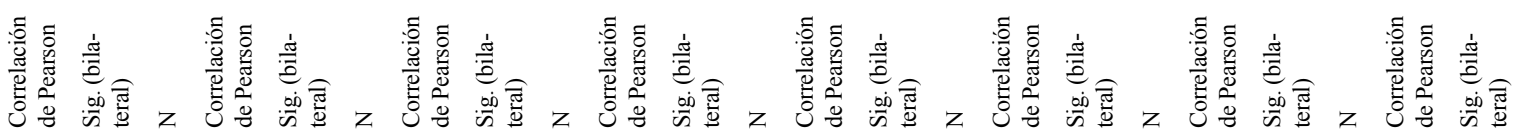




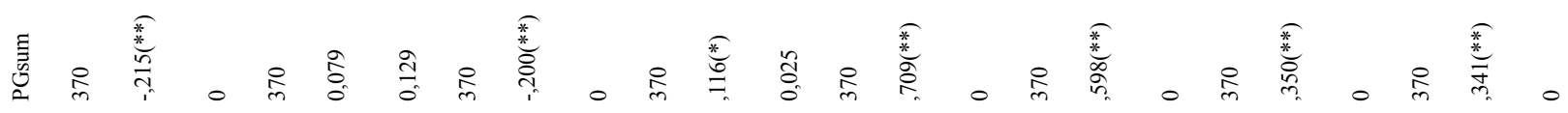

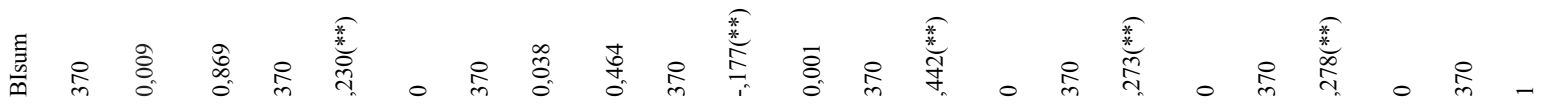

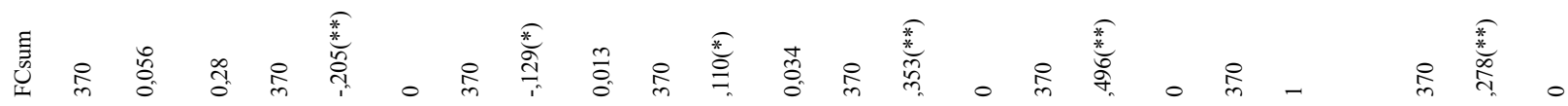

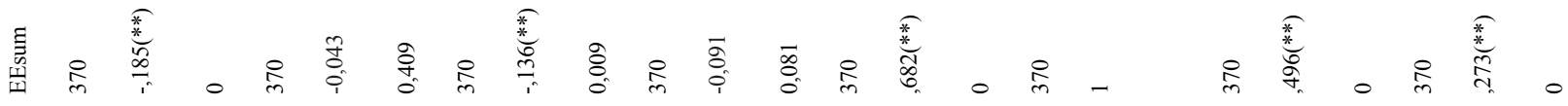

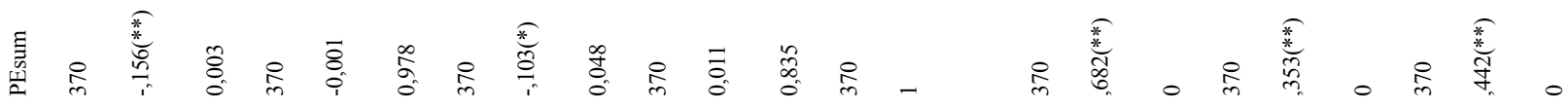

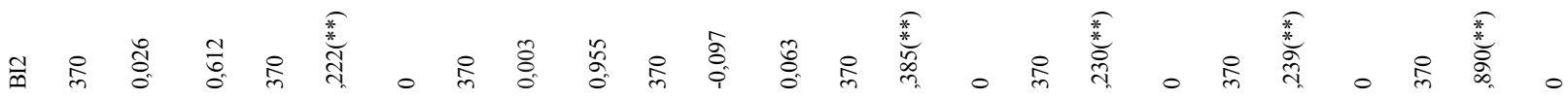

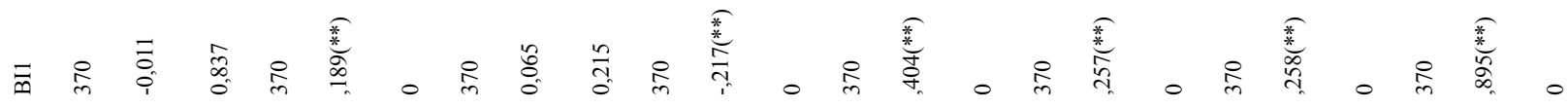

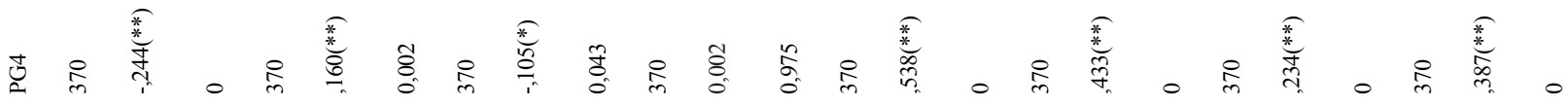

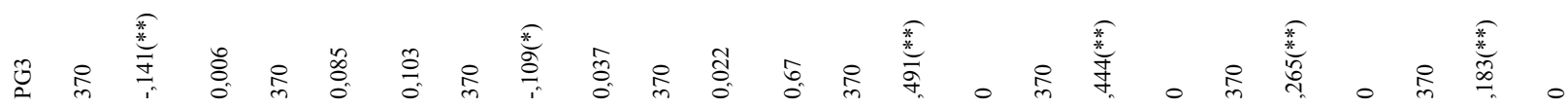

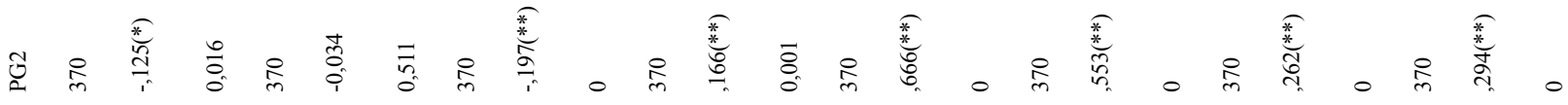

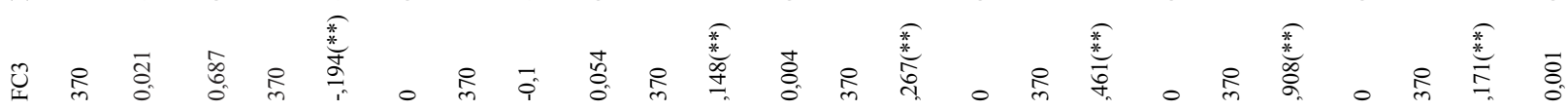

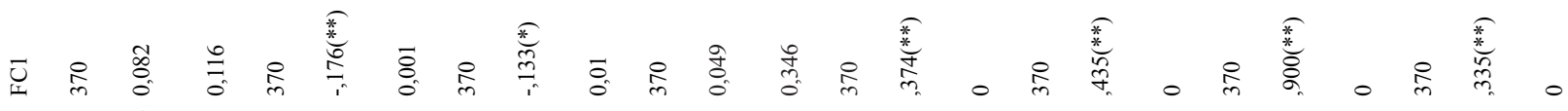

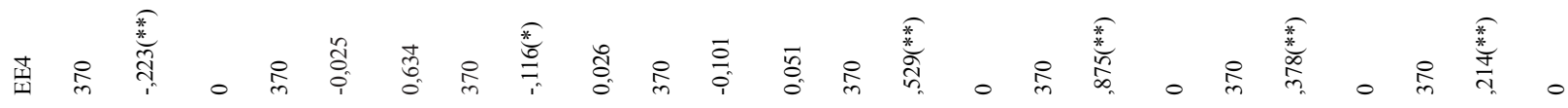

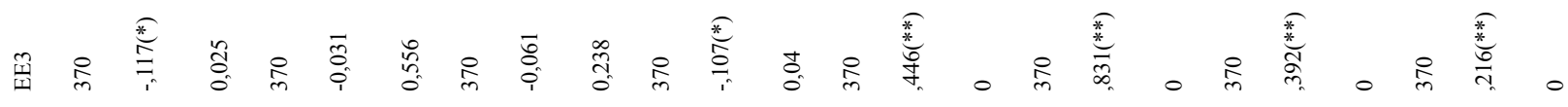

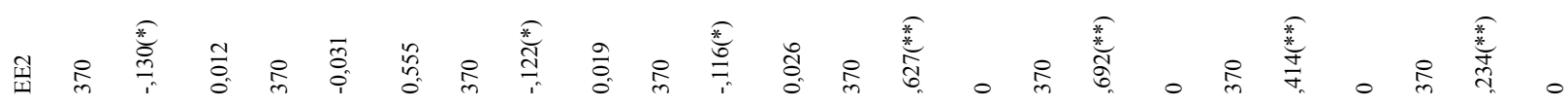

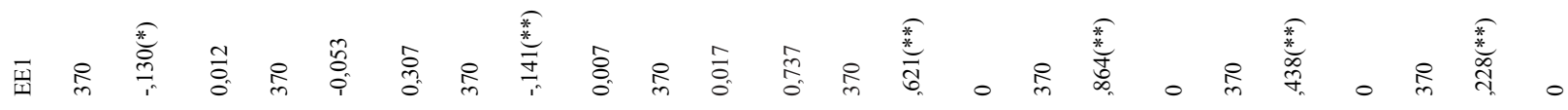

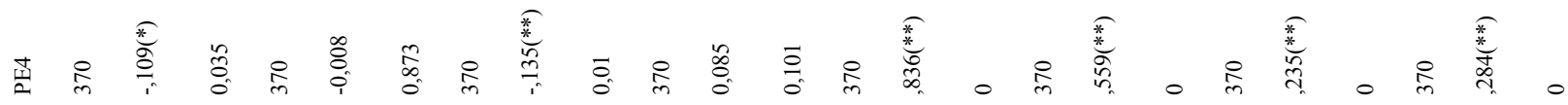

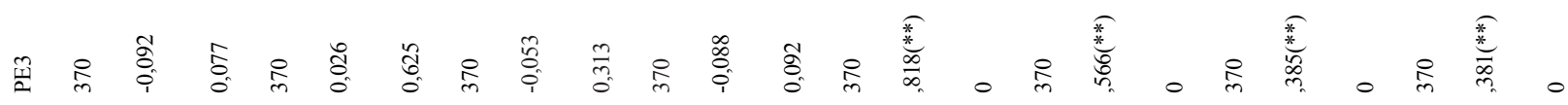

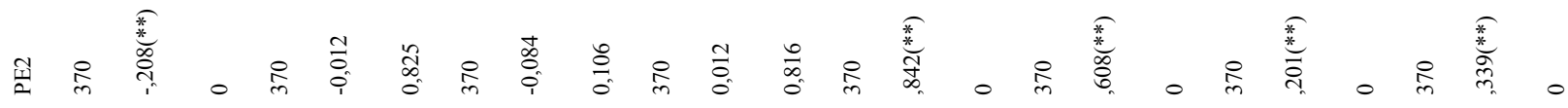

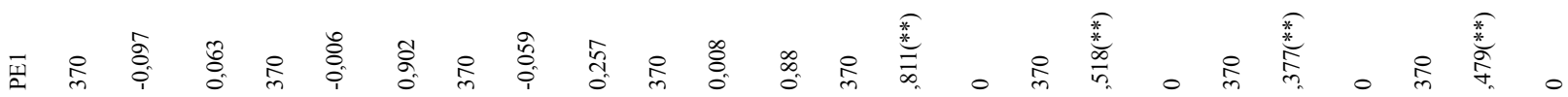

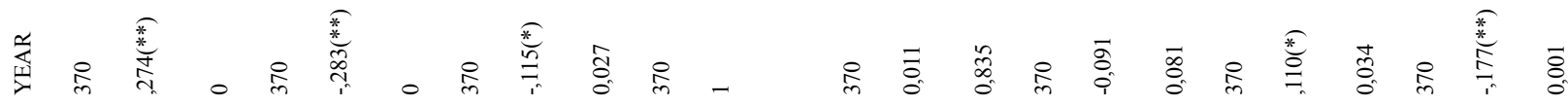

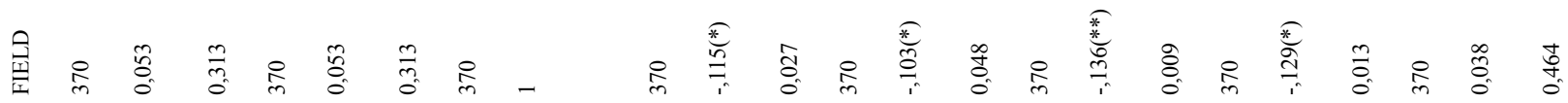

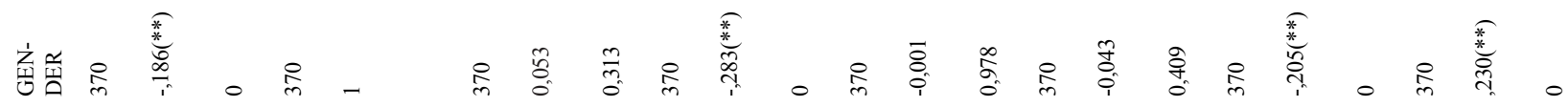
岩房- \&

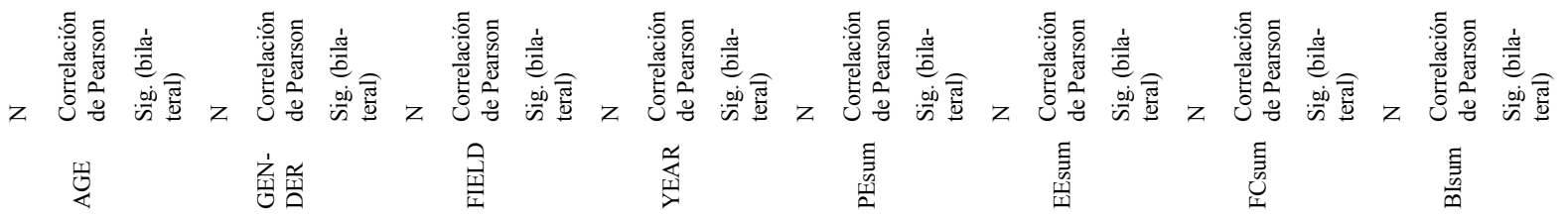




$$
\begin{aligned}
& \text { 竞呑- 只 } \\
& \text { 言番悉。号 }
\end{aligned}
$$

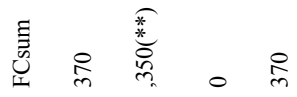

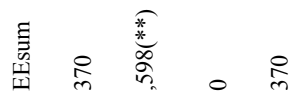

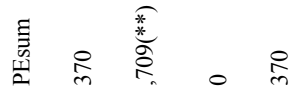

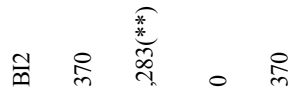

$$
\begin{aligned}
& \text { 㐫呑荧 }
\end{aligned}
$$

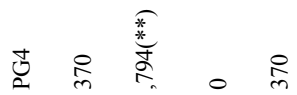

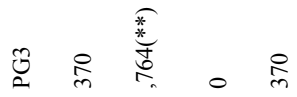

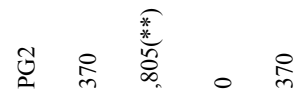

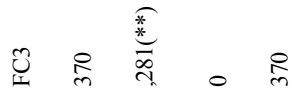

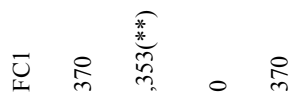

$$
\begin{aligned}
& \text { 苗点㗬。品 }
\end{aligned}
$$

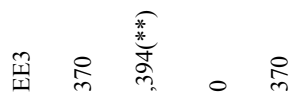

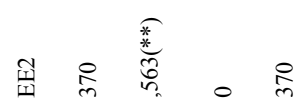

$$
\begin{aligned}
& \text { 田尽裳。方 } \\
& \text { 苗呑悉。觉 } \\
& \text { 舀呑裳。品 }
\end{aligned}
$$

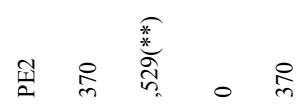

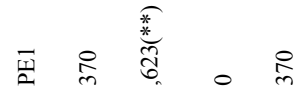

$$
\begin{aligned}
& \text { 苂 尺 }
\end{aligned}
$$

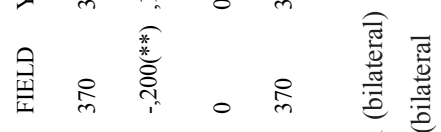

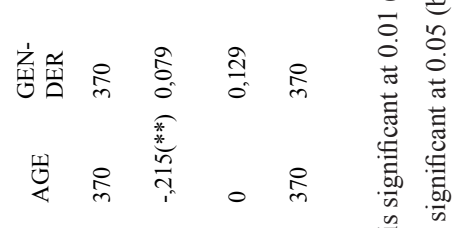

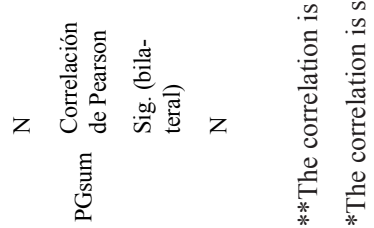

